Ann. Génét. Sél. anim., I969, 1 (4), 349-378.

\title{
ANATOMIC AND GYTOGENETIC STUDIES ON 19 HORNLESS GOATS WITH SEXUAL DISORDERS
}

\author{
Parvathi-K. BASRUR and H. KANAGAWA \\ Department of Biomedical Sciences, \\ University of Guelph, \\ Guelph, Ontario (Canada)
}

\begin{abstract}
Of nineteen polled Saanen goats with sexual disorders three were genetically male XY, two were $\mathrm{XX} / \mathrm{XY}$ chimeras and forteen were females $\mathrm{XX}$.
\end{abstract}

An earlier report (BASRUR and KANAGAwA, I968) summarized our observations on the anatomic and cytogenetic features of II intersex Saanen goats. Since then we have examined 8 more goats with sex anomalies. In this communication we present a more detailed description of our findings on all 19 of these animals.

Six of the goats included in this study (Table I) appeared to be closer to the female phenotype on the basis of general conformation and external genitalia (Nos. I4-I9) while two had a beard, the general appearance and descended testes resembling males. The descended testes of these two goats (Nos. I and 2) were approximately of the same size as those of normal male although the cleft at the midline in these animals appeared to be more prominent (Figs. I and 2). One of the intersexes (No. 3) which also exhibited descended testes (Fig. 4) was different from the two " phenotypic males" (Nos. I and 2) in that the scrotum was much smaller and the penis, although relatively small, was present. In goat No. I a small protuberance was noted near the urethral opening whereas in goat No. 2 no indication of a penis or enlarged clitoris was noticeable (Fig. 2). The external orifices in these animals were either circumscribed by an indistinct fold of skin as in goat No. 2 (Fig. 2) or represented by an extremely narrow opening near the inconspicuous protuberance (Fig. 5). 
TABLE I

General appearance, cytological sex and reproductive organs of 19 Saanen goats with sex anomalies

Aspect extérieur, sexe cytologique et organes reproducteurs de 19 chèvres Saanen avec anomalies sexuelles

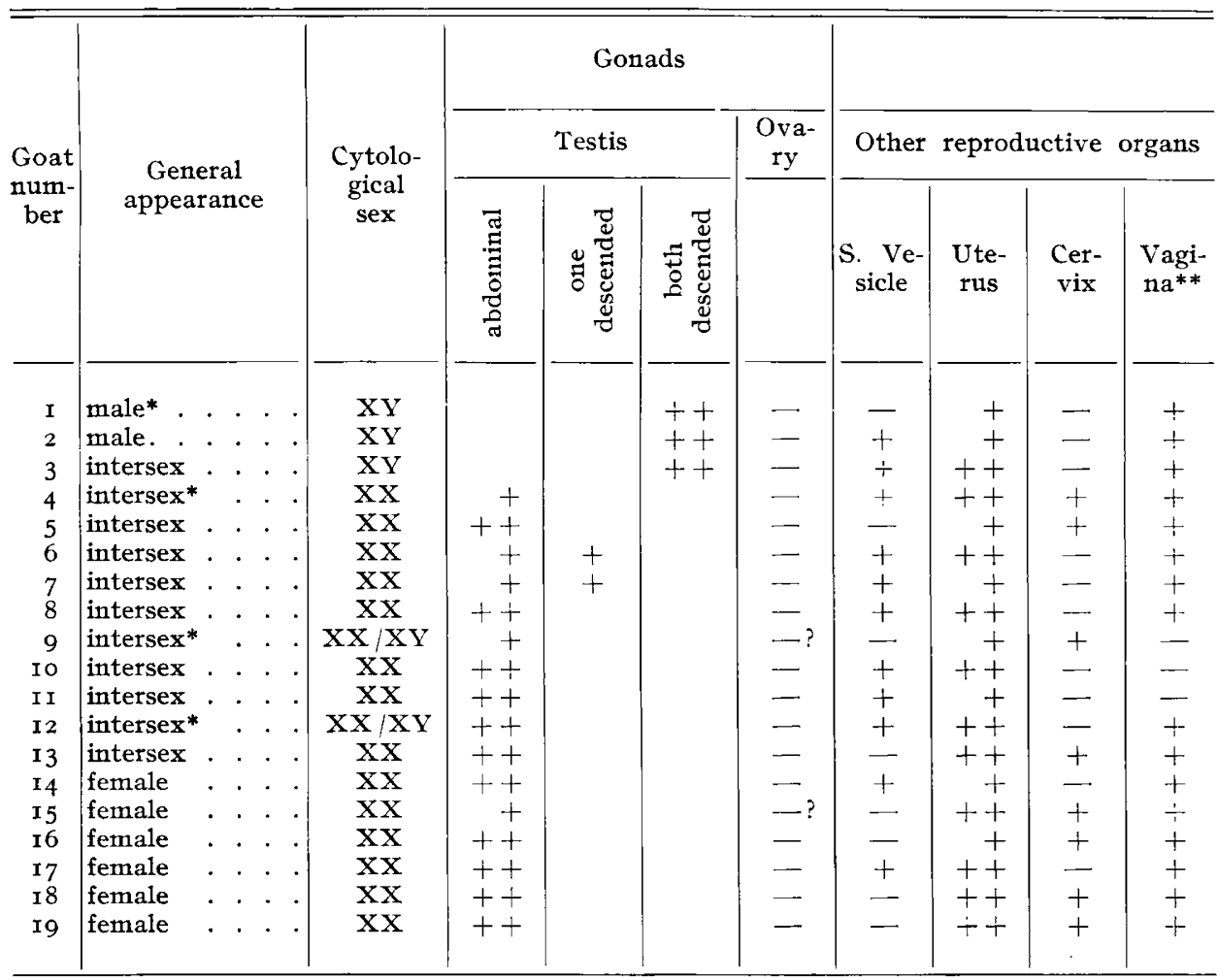

* Twin ;

** Enlarged “ vagina-like " structure.

The external genitalia in all except these 3 goats (Nos. I-3) were represented by a vulva including a long slit-like urethral opening and an enlarged clitoris (Fig. 3). In two of the phenotypic intersexes (Nos. 6 and 7) an unilateral scrotal sac with palpable gonad was noted (Fig. 3). With the exception of these 5 goats all the others had either inconspicuous scrotal sacs or no scrotum at all.

In all the intersexes described in this report the gonads were represented by testes which in a majority of cases were bilateral and intra-abdominal. The exceptions include the 5 goats already described and 3 goats (Nos. 4, 9, and I $_{5}$ ) in which a gonad was noted only on one side. In goat No. 3 a testislike mass surrounded by connective tissue and measuring $3 \mathrm{~cm}$ in diameter was noted in the position where intra-abdominal testes were generally detected.

A well developed uterus with uterine horns and " body" was present in 
I I goats ('Table I) while the others, lacking uterine horns, exhibited a wide variation in the size and internal layers of the uterine body (Figs. 7-9). Seminal vesiclelike structures and the bulbo urethral glands were noted in 8 animals in the enlarged lower part of the urogenital system. This enlarged structure has been described as " modified vagina " by earlier investigators in this field (DAvIEs, I9I3; HILL, I94I; SOMERVAIL, I937) and more recently by SHORT, et al. (I968) and HAMERTON, et al. (IG69). This organ which exhibits a wide variation (Fig. IO-I4) in intersexes (BASRUR and KANAGAWA, in preparation) was noted in all intersexes although in 3 goats they were narrow and almost tube-like. Cervix-like structures were noted in the " modified vagina " of II goats. In some instances, rudimentary seminal vesicle and cervix-like structures were seen in the same sections (Figs. IoI4). Paired vas deferens were present in all cases including the 3 cases (Nos. 4, $\left.9,1_{5}\right)$ in which a testis was noted only on one side.

The testes were generally hypoplastic and the seminiferous tubules were devoid of germ cells in most cases (Fig. I5) including goat No. 3 which had a pair of descended testes and an intra-abdominal fibrous mass resembling a testis (Fig. I6). Histologic and ultrastructural features of the gonads in a majority of cases were indicative of extreme degeneration (Fig. I7). In some instances the lining cells of the seminiferous tubules appeared to be separated by thickened intercellular extensions of the basement membrane from which fiber-like projections stretched out into the cytoplasm (Fig. I8).

Examination of testicular tissues in 4 cases (Nos. I, 2, 5, I4) revealed indications of meiotic activity in some tubules although these were interspersed between apparently inactive tubules (Figs. I9 and 20). All these goats exhibited collapse of seminiferous tubules between which masses of deeply staining materials reminiscent of degenerating germ cells were frequently noted (Fig. 2I). Goat No. 5 which was 8 months old at the time of sacrifice, and goat No. I4 which was I4 months old, exhibited several tubules with meiotic activity (Figs. 2I, 22). However, spermatozoa in these cases were extremely distorted, indicating interrupted or abnormal spermiogenesis (Figs. 23-25).

In a majority of phenotypic intersexes, the epididymis was relatively larger and generally devoid of sperms (Fig. 26). Even though the increase in epididymal size in comparison to the testis was not more pronounced (Fig. 27) in the 3 goats with descended testes (Nos. I-3) the histologic sections of two of these goats (Nos. I and 2) showed masses of sperms, macrophage infiltration and other signs of degeneration (Figs. 28-30) probably similar to those accompanying epididymal blockage (Soliter et al. I969).

Ovary-like structures were noted attached to the abdominal testes on one side in 2 cases (Nos. 9, I5); however, on histologic examination, these appeared to be extensions of epididymal duct system surrounded by connective tissue with no sign of female germ cells or granulosa cells.

Chromosome distribution in the peripheral blood cultures of the I9 goats is presented in Table 2. The recognition of the sex complements of these goats is relatively simple since in normal female goats all autosomes and the $\mathrm{X}$ chromosome are acrocentric while the $\mathrm{Y}$ in the male is a small metacentric (BASRUR and SToL,TZ, r967). 
TABLE 2

Chromosome distribution and sex complements of I9 Saanen goats with sex anomalies

Distribution des chromosomes et hétérosomes de I9 chèvres Saanen avec anomalies sexuelles

\begin{tabular}{|c|c|c|c|c|c|c|c|c|c|}
\hline \multirow{2}{*}{$\begin{array}{c}\text { Goat } \\
\text { number }\end{array}$} & \multirow{2}{*}{$\begin{array}{l}\text { Number of } \\
\text { cells counted }\end{array}$} & \multicolumn{7}{|c|}{ Cells in diploid range } & \multirow{2}{*}{$\begin{array}{c}\text { Sex } \\
\text { complements }\end{array}$} \\
\hline & & 57 & 58 & 59 & 60 & $6 \mathbf{I}$ & 62 & 63 & \\
\hline $\mathbf{I}$ & $5^{8}$ & 3 & 3 & 5 & 42 & 4 & o & I & $\mathrm{XY}$ \\
\hline 2 & $5^{2}$ & I & 2 & 2 & $4 \mathrm{I}$ & 3 & 2 & I & $\mathrm{XY}$ \\
\hline 3 & 65 & 2 & 1 & 4 & 53 & 3 & o & 2 & $\mathrm{XY}$ \\
\hline 4 & $5^{2}$ & 2 & 4 & 2 & 34 & 6 & I & 3 & $\mathrm{xx}$ \\
\hline 5 & 22 & o & I & I & 19 & $\mathrm{o}$ & I & o & $\mathrm{xx}$ \\
\hline 6 & 40 & o & 0 & 2 & 34 & 2 & I & I & $\mathrm{xx}$ \\
\hline 7 & 40 & o & 2 & I & 36 & $\mathrm{r}$ & o & $\mathrm{o}$ & $\mathrm{xx}$ \\
\hline 8 & 33 & I & I & o & 27 & 2 & I & I & $\mathrm{xx}$ \\
\hline 9 & 45 & o & I & I & $38 / 3$ & I & I & o & $\mathrm{XX} / \mathrm{XY}^{*}$ \\
\hline Io & $3 \mathrm{I}$ & I & 2 & I & 26 & o & I & o & $\mathrm{xx}$ \\
\hline I I & 33 & I & 2 & I & 28 & o & I & o & $\mathrm{xx}$ \\
\hline 12 & 24 & I & I & I & $19 / 1$ & o & I & o & $\mathrm{XX} / \mathrm{XY}^{*}$ \\
\hline I3 & 34 & o & 2 & 2 & 28 & o & I & I & Xx \\
\hline I 4 & 44 & o & o & o & 44 & o & o & o & $\mathrm{xx}$ \\
\hline I 5 & $7 \mathrm{I}$ & 3 & 4 & 3 & $5 \mathrm{I}$ & 7 & 3 & o & $\mathrm{xx}$ \\
\hline 16 & 30 & I & o & o & 27 & I & o & I & $\mathrm{xx}$ \\
\hline I7 & 57 & I & o & 3 & $5 \mathrm{I}$ & I & I & o & $\mathrm{xx}$ \\
\hline 18 & 28 & I & I & I & 24 & I & o & o & $\mathrm{xx}$ \\
\hline I9 & 28 & o & I & o & 26 & I & o & o & $\mathrm{xx}$ \\
\hline
\end{tabular}

* Three cells in goat No. 9 and one cell in goat No. I2, were of XY type.

All animals exhibited 60 chromosomes (Figs. 3I, 32) in a majority of cells, excepting one case (No. I5) which had 6I chromosomes in 7 out of the 7 I cells counted. On the basis of sex complements alone, 3 (Nos. I-3) out of the I9 were genetic males while 2 (Nos. 9 and I2) were chimeras exhibiting 3 out of 45 and one out of 24 cells respectively, of XY make-up. The remaining $\mathrm{I}_{4}$ were genetic females, including the mosaic (No. I5) with the 2 cell types carrying 60 and $6 \mathrm{I}$ chromosomes respectively.

Previous studies on intersex goats have shown that they are genetic females lacking a characteristic Y chromosome (BASRUR and COUBROUGH, I964; DE GROUCHY et al. I965). Fourteen of our goats could be grouped under this category. The three cases with XY constitution (Table I) were not subjected to exhaustive histologic and anatomic examination at the time they were reported in a preliminary communication (BASRUR and KANAGAWA, I968). As previously mentioned they exhibited a slight enlargement of the epididymis and nearly normal size testes. These could well belong to the category of " sterile males " with epididymal defect also demonstrated to be genetic males on the basis that the histopathologic changes noted in the epididymis of our XY goats seem to resemble those 
described by SolfER et al. (I969). The interesting finding regarding our three genetic males was the presence of a uterine body with unmistakable endometrial tissue (Fig. 8) and the absence of penis (Fig. 3). The presence of an uterus coupled with the absence of penis was the basis for our grouping these genetic males as intersexes in our previous report (BASRUR and KANAGAWA, I968). The genetic male goats with epididymal defects reported by Sor, ER et al. (I969) and similar cases reported as sterile males by HAMERTON et al. (I969) were apparently without any overt intersex characteristics. KocH, ( 1963 ) had reported that some of the polled male goats were known to exhibit female characteristics including lactation. It is conceivable that the genetic males included in our studies are homozygous for the polled gene $(P P)$. Some of the presumed PP male goats have been demonstrated to exhibit reproductive anomalies (WEBER, I969; CORTEEL et al., I969). The intersexual traits noted in the 3 genetic males may well be varying expressions of the polled genes in homozygous condition.

Among our goats, two were noted with $\mathrm{XX} / \mathrm{XY}$ chimerism although the proportion of male cells in both were strikingly low. These animals probably represent the freemartin-like condition demonstrated in the goat by PADEH et al. (I965) and more recently by ILBERY and WILLIAMS (I967).

It is evident from our observations as well as from those of others (HAMERTON et al., I969; SOLLER et al., I969) that the degree of intersexuality evident from general appearance and anatomical features, vary from a stronger female phenotype to a predominantly male type. In intersexes grouped as phenotypic females, the general appearance and external genitalia resembled normal females more closely, even though they also had abdominal testes. Those of a predominantly male type general appearance had both descended testes but lacked a penis and exhibited an unequivocal uterus. Thus, in these intersexes there was no correlation between the extent of intersexuality on the basis of microscopic and/or anatomic finding and the genetic sex based on chromosome analysis.

In a majority of goats included in our study, testicular cells were inactive, however, meiotic activity was unmistakable in four intersexes, two of which were genetic males. Our observations thus differ from those of HAMERTON et al. (I969) who had reported total absence of spermatogenesis in the 35 intersex goats they have studied. On the other hand in the goats we have examined, no indication of ovarian tissue was detected even though HAMERTON et al. (I969) have reported ovotestes in 3 cases. Previous studies by other investigators on intersex goats have also failed to reveal ovarian tissues (DAvIES, I9I3; SoMERVAIL, I937; HILL, I94I) although hermaphrodites with ovotestes have been observed occasionally in members of heterosexual twins in polled goats and among horned dairy goats (EATON, I945; DIVEKAR, I953).

It is generally accepted that intersexes are invariably sterile; however, intersexes among pigs (HULLAND, I964; BREEUWSMA, I969) and sex reversed domestic chicken (MILLER, I938; VAN TIEnhoven, I968) have been known to be meiotically active. The possibility also exists that the two intersex goats (Nos. 5 and I4) are chimeras resulting from double fertilization and fusion of the egg with its retained polarbody. A similar situation in an adult male with completely normal sexual development has been reported in humans (GARTLER et al. I962; 
ZUELZER, et al. I964). Since our cytogenetic characterization of these goats relies entirely on cultured leukocytes, there is a possibility that the other tissues of these two goats are chimeric. However, some XY cells would have been detected in blood cultures provided both cell types have equal genetic and selective advantages in the culture environment. ILBERY and WILLIAMS (I967) have reported that in a Toggenburg goat, which was confirmed to be a blood chimera, one $\mathrm{XY}$ cell was noted among the roo metaphase plates examined. The fact that the proportion of XY cells were remarkably low in two chimeric intersexes (Nos. 9 and 12 ) included in the present study strongly suggests a selective disadvantage of $\mathrm{XY}$ cells in blood cultures.

Rę̧u pour publication en décembre 1969.

\section{ACKNOWLEDGMENTS}

We thank Dr. J.-P.-W. GrLman for histologic characterization of the reproductive system in these goats. We are also indebted to Dr. C.-A.-V. BAR KER, Department of Clinical Studies, for supplying the intersex goats and helping us to contact various goat breeders in Ontario. This investigation was supported by National Research Council of Canada.

\section{SUMMARY}

Chromosome analysis was carried out on cultures of peripheral blood from 19 Saanen goats with sex anomalies $(8+11$ described briefly in a 1968 report). Two of these goats had stronger phenotypic resemblance to males while the remaining 17 cases varied in the degree of morphojogic leanings towards females. Two male-like goats and an animal born co-twin to one of these " males " were genetic males. All three had reduced normal external male genitalia, a small uterus and enlarged epididymis. One may assure that this animals belong in the category of " sterile males with epididymal defect ", the new finding in these cases being that they possess uterus. Two phenotypic intersexes which were co-twin of males were blood chimeras exhibiting a strikingly small proportion of XY cells and are, perhaps freemartins. The remaining 14 cases were genetic females including one which was a mosaic with 2 cell types carrying 60 and 61 chromosomes in peripheral blood. Two goats of XX constitution and two with XY exhibited testicular activity although spermatogenesis appeared to be abnormal in all these cases. A consistent feature of these intersexes was that all of them carried male gonads and an uterus while ovarian tissues were invariably absent. The accessory glands exhibited varying degrees of intersexual combinations. A pair of well developed vas deferens was noted in all intersexes including the 3 cases in which a male gonad was detected only on one side.

\section{RÉSUMÉ}

\section{ÉTUdes ANATOMIQUES ET CYTOGÉNÉTIQUES DE I9 ChÈVRES SANS CORNES PRÉSENTANT DES DÉFAUTS SEXUELS}

Le caryotype de 19 chèvres Saanen sans cornes atteintes d'anomalies sexuelles $(8+11$ brièvement décrites dans une note de 1968) a été établi à partir de culture de sang périphérique. Deux de ces animaux ressemblaient fortement à des mâles alors que les dix-sept autres se rapprochaient plus ou moins des femelles par leur apparence extérieure. Les deux animaux d'aspect mâle ainsi qu'une autre chèvre, née jumelle d'un de ces " mâles ", étaient génétiquement des mâles. Tous les trois avaient des organes génitaux externes de type mâle réduits, un petit utérus et l'épididyme hypertrophié. On peut supposer que ces sujets appartenaient à la catégorie des 
" mâles stériles à défauts épididymaires "; la nouveauté des présents examens étant la présence d'un utérus. Deux intersexués phénotypiques, nés jumeaux de mâles présentaient des chimères sanguines avec une faible mais frappante proportion de cellules XY. Ils sont peut-être des freemartins. Les 14 autres cas étaient génétiquement des femelles y compris un qui présentait une mosaïque à deux types de cellules dans le sang périphérique avec, respectivement, 60 et 61 chromosomes. Deux chèvres de constitution XX et deux de constitution XY présentaient une activité testiculaire, cependant la spermatogénèse était anormale, dans tous les cas. D'une manière constante tous les intersexués avaient des gonades de type mâle et un utérus alors que les tissus de type ovarien étaient invariablement absents. Pour les glandes accessoires on notait des degrés variables de combinaisons intersexuées. Enfin, on observait une paire de vaisseaux spermatiques chez tous les intersexués, y compris chez les trois animaux porteurs d'une seule gonade.

\section{REFERENCES}

BASRUR P. K., Coubrough R. I., 1964. Anatomical and cytological sex of a Saanen goat. Cytogenetics, 3, 414-426.

Basrur P. K., Kanagawa H., 1968. Cytogenetic studies on intersex goats. Canad. J.Genet. Cytol., 10, 764 .

BASRUR P. K., Stoltz D. R., I967. The Y Chromosome of the goat. J. Hered., 48, 261-262.

Breeuwsma A. J., I969. Personal communication.

Corteel J. M., Hulot Françoise, Courot M., Attal J., Philippon A., I969. Examens morphologiques, caryologiques, physiologiques et pathologiques de boucs stériles sans cornes. Ann. Génét. Sél. anim., 1. $34 \mathrm{I}-348$.

Davies C. J., I913. Caprine freemartins. Veter. J., 69, 62-70.

De Grouchy J., I.auvergne J.-J. et Ricordeau G., 1965. Études cytogénétiques chez 16 chèvres intersexuées. C. R. Acad. Sci., 260, 2932-2935.

DIVEKaR K. V., 1953. A case of hermaphrodism in a horned milk goat. Ind. veter. J., 29, 538-540.

EATON N. E., 1945. The relation between polled and hermaphrodite characteristics in dairy goats. Genetics, $30,5 \mathrm{I}-6 \mathrm{I}$.

Gartler S. M., WAXMan S. H., Giblet E., 1962. An XX/XY human hermaphrodite resulting from double fertilization. Proc. nation. Acad. U. S., 48, 332-335.

Hamerton J. L., Dickson J. M., Pollard C. E., Grièves S. A., Short R. V., r969. Genetic intersexuality in goats. J. Reprod. Fert., Suppl., 7, 25-5I.

HILL R. T., I94I. Abnormal sex anatomy of a goat. Endocrinology, 29, 1003-roo7.

Hulland T. J., 1964. Pregnancy in a hermaphrodite sow. Canad. veter. J., 5, 39-40.

IlBERY P. L., WILliams D., 1967. Evidence of the freemartin condition in the goat. Cytogenetics, 6, $271-285$.

KOCH W., I963. Intersexuality in mammals. In OVERSIER Intersexuality. Academic Press, Iondon and New York.

MILLER R.-A., I938. Spermatogenesis in a sex reversed female and in normal males of the domestic fowl, Gallus domesticus. Anat. Rec., 70, I55-189.

Padeh B., Wysoki M., Ayalon N., Soller M., r965. An XX/XY hermaphrodite in the goat. Israel J. med. Sci., 1, roo8-ror 2.

Soller M., Padeh B., WYsoki M., Ayalon N., 1969. Cytogenetic of Saanen goats showing abnormal development of reproductive tract associated with the dominant gene for polledness. Cytogenetics, $8,5 \mathrm{I}-67$.

SomerVaIL, M. I., 1937. Intersexual development in a goat. Veter. J., 93, 60-6r.

TIENhoben VAN A., 1968. Reproductive physiology of vertebrates. W. B. Saunders Co., Philadelphia, I,ondon and Toronto.

Weber W., 1969. La stérilité des mâles dans les races caprines suisses sans cornes. Ann. Génét. Sél. anim., 1. $379-382$.

ZUelzer W. W., Beattie K. M. and Reisman L. E., I964. Generalized unbalanced mosaicism attributable to dispermy and probably fertilization of a polar body. Amer. J. Human Genet., 16, 38-5I. 


\section{PLATE I}

FIGs. I-4. External genitalia of some of the Saanen goats with sex anomalies.

FIG. I. Goat No. I showing descended testes with prominent midline cleft.

FIG. 2. Goat No. 2 showing descended testes with midline cleft and the absence of a penis. Note that the urethral opening is indistinct and unaccompanied by penis or clitoris-like structure.

FIG. 3. Goat No. 6 with a descended testis on the left $(T)$, the narrow slit-like urethral opening $(U)$ a distinct vulvar opening $(V)$ and enlarged clitoris $(C)$.

FIG. 4. Goat No. 3 with a pair of descended testes. Note the relatively small scrotal sac and the small penis.

\section{PLANCHE I}

FIg. 1 à 4. Organes génitaux externes de quelques chèvres Saanen présentant des anomalies sexuelles.

FIG. I. Chèvre $n^{\circ}$ I montrant des testicules descendus avec fente médiane prononcée.

Frg. 2. Chèvre $n^{\circ} 2$ montrant des testicules descendus avec fente médiane et absence de pénis. Noter que l'ouverture urétrale est indistincte et n'est pas accompagnée par une structure pénienne ou clitoridienne.

Frg. 3. Chèvre $n^{0} 6$ avec un testicule descendu à gauche ( $T$ ), une ouverture urétrale en forme de fente étroite (U), une ouverture vulvaire distincte (V) et un clitoris hypertrophié (C).

FIG. 4. Chèvre $n^{0} 3$ avec une paire de testicules descendus. Noter le relativement petit sac scrotal et le petit pénis. 

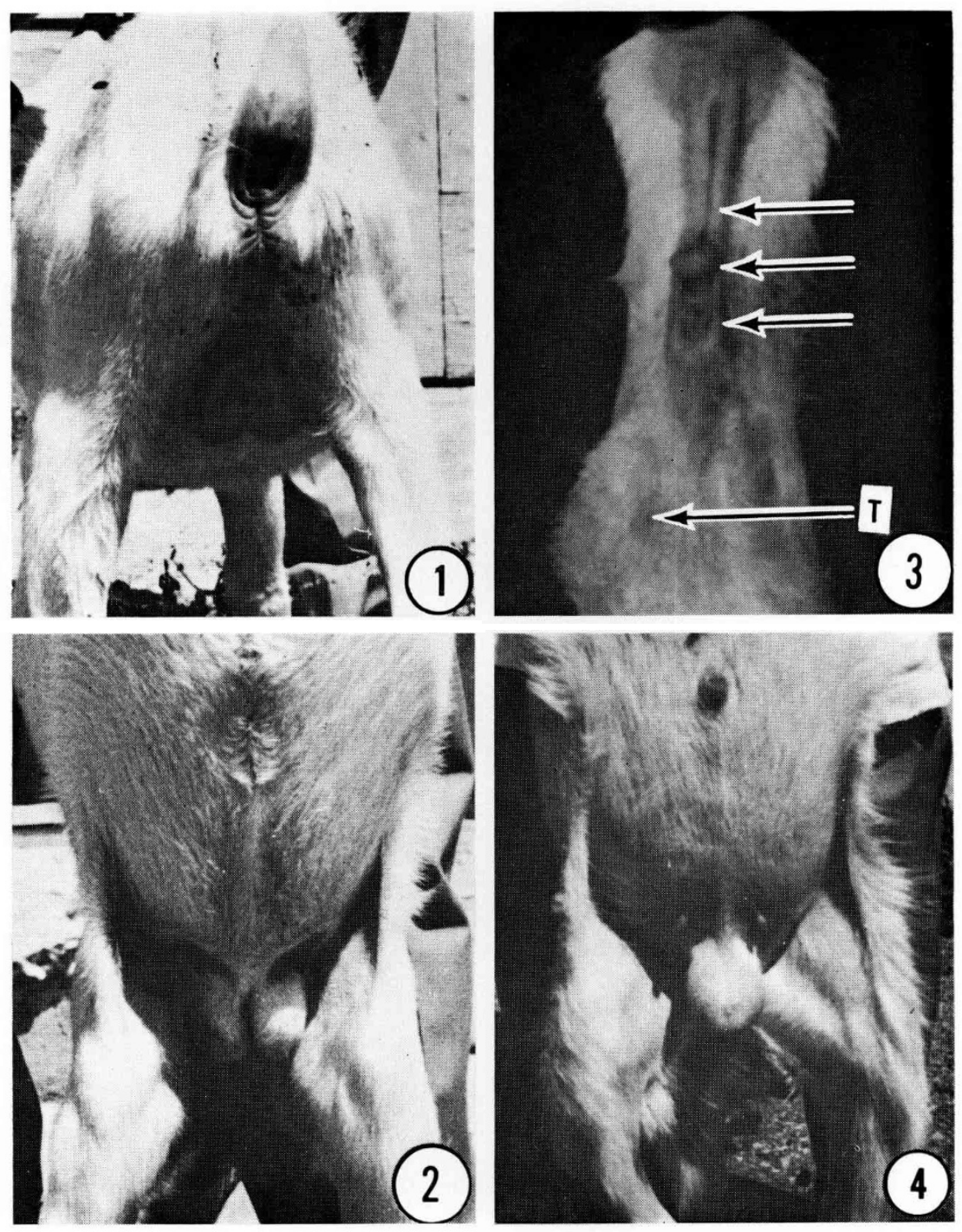

P.-K. BASRUR and H. KANAGAWA 


\section{PLATE II}

FIGs. 5 and 6. Internal genitalia of two goats showing bilaterally descended (Goat No. I) and unilaterally descended (Goat No. 7) testes. P: small protruberance near the urethral opening noted in Goat No. I; $V$ : vaginalike structure; $B$ : bladder $S:$ seminal vesicles $E:$ uterus ; $T$ : testes ; E: epididymis.

\section{PLANCHE II}

FIG. 5 et 6 . Organes génitaux internes de deux chèvres présentant des testicules descendus bilatéralement (chèvre $n^{\circ}$ ) et unilatéralement (chèvre $\left.n^{\circ} 7\right) . P$ : petite protubérance près de l'ouverture urétrale notée sur la chèvre $n^{\circ} \mathrm{I} ; \mathrm{V}:$ structure de type vaginal; $\mathrm{B}$ : vessie; $\mathrm{S}$ : vésicules séminales; $\mathrm{U}:$ utérus; $\mathrm{T}$ : testicules; $\mathrm{E}$ : épididyme. 

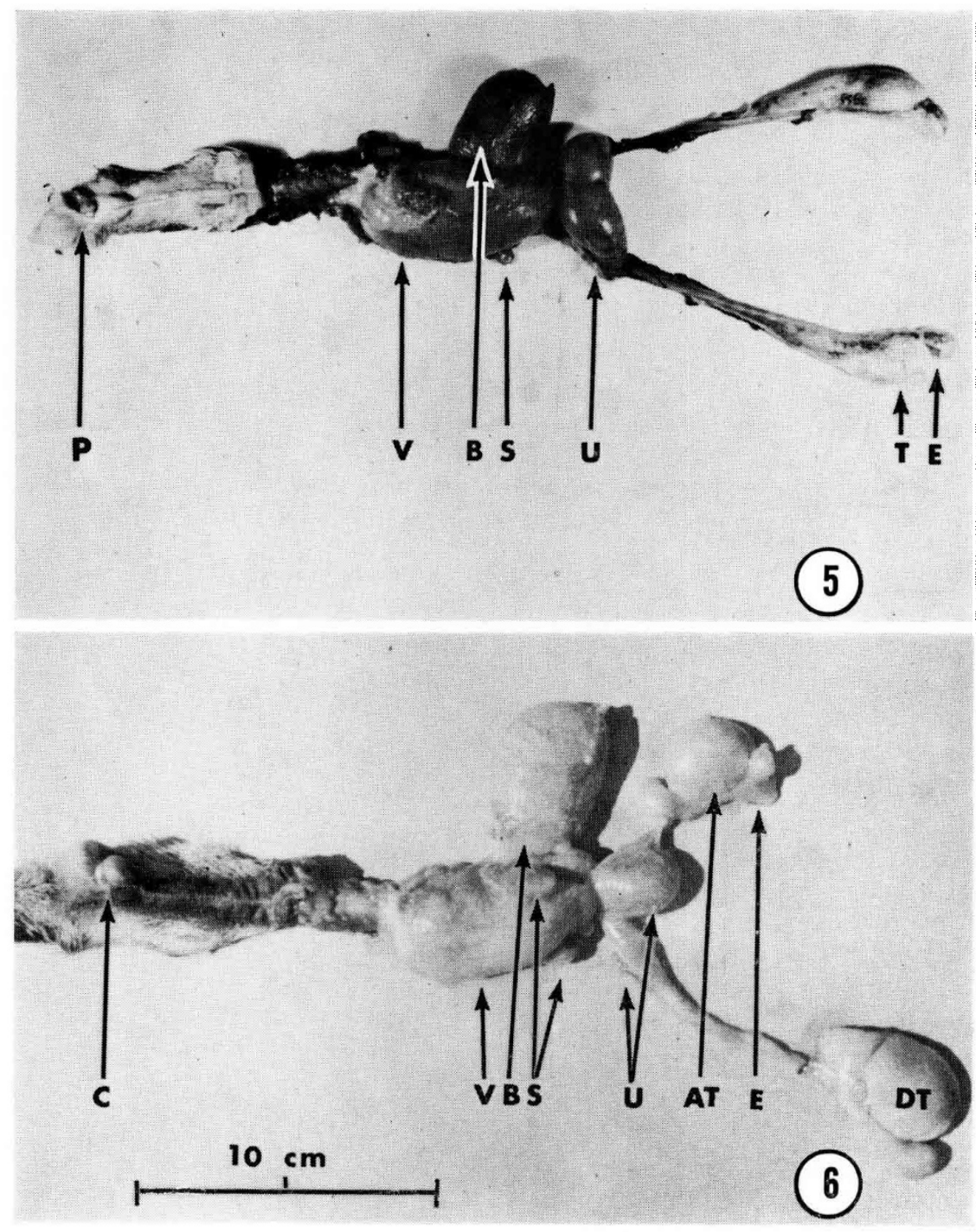

P.-K. BASRUR and H. KANAGAWA 


\section{PLATE III}

FIGS. 7-9. Histological sections of the uterine wall from intersexes showing varying degrees of differentiation.

FIG. 7. Goat No. I exhibiting glandular nature of the "endometrium "and the layers of muscle cells resembling those of myometrium.

FIG. 8. Glandular endometrium and part of the myometrium in Goat No. 2.

FIG. 9. Uterine epithelium of goat No. 1o shoxing some glandular structures.

\section{PLANCHE III}

FIg. 7 à 9 . Coupes histologiques de la paroi utérine d'intersexués montrant des degrés variés de différenciation.

Fig. 7. Chèvre $n^{\circ}$ I présentant une nature glandulaire de l'endomètre, les couches de cellules musculaires ressemblant à celles d'un myomètre.

Fig. 8. Endomètre glandulaire et partie du myomètre de la chèvre $n^{\circ} 2$.

Fig. 9. Epithélium utérin de la chèvre $n^{\circ}$ ro montrant quelques structures glandulaires. 


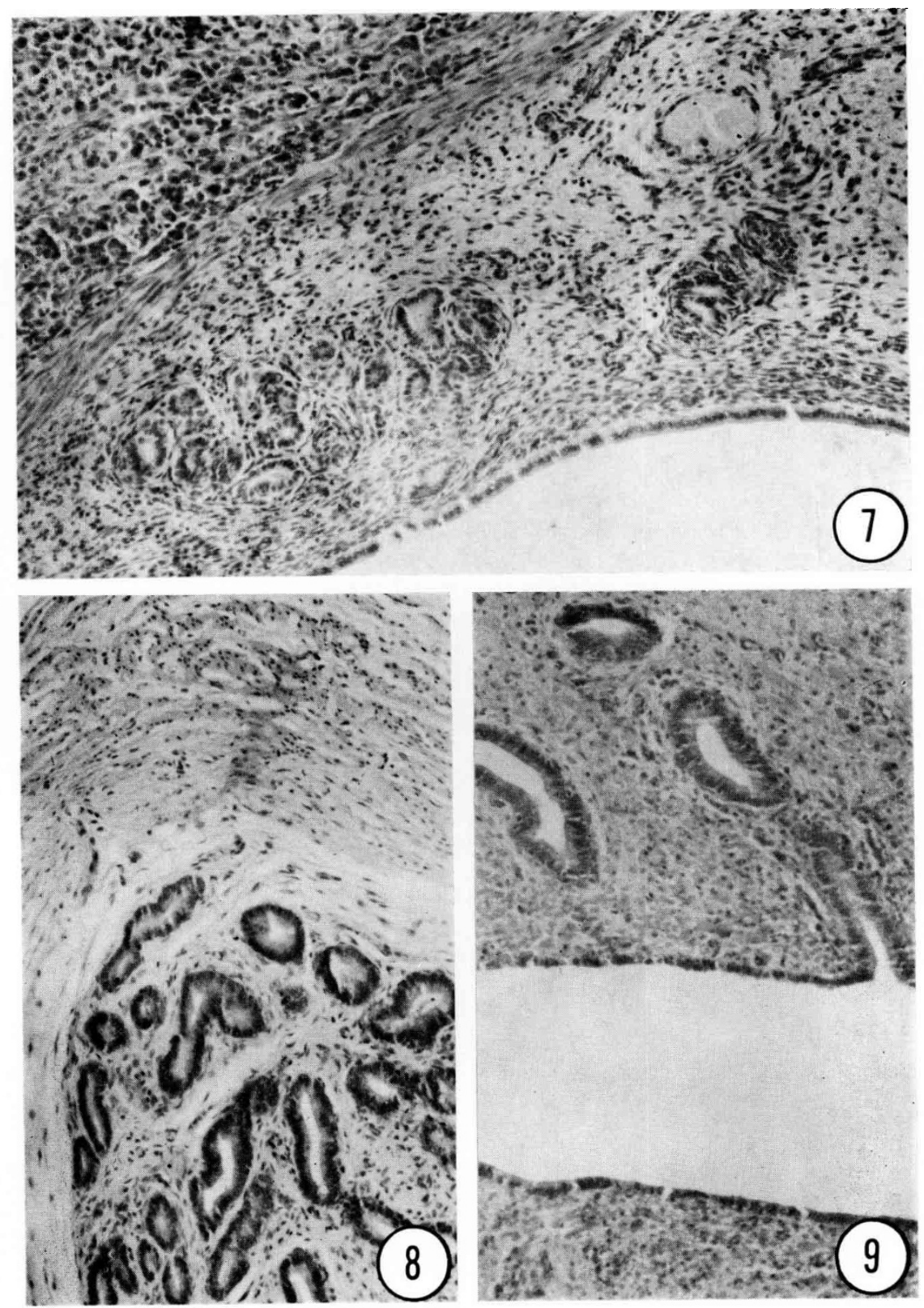




\section{PLATE IV}

FIGS. IO-I4. Histological sections from several areas of the " modified vagina" in goat No. 4 . FIG. I0. Low power micrograph of the " modified vagina" showing smaller lumens and glands on the wall. FIG. II. Cervix-like lining of the main lumen of the " modified vagina".

FIG. I2. Seminal vesicle-like structure situated on the inner wall of the smaller lumen.

FIG. I3. A section from the lower part of the " modified vagina" showing seminal vesicle-like and cervixlike structures.

FIG. 14. Internal lining of the smaller lumen on the side opposite to the seminal vesicle-like structure.

\section{PLANCHE IV}

FIg. 10 à 14. Coupes histologiques de quelques zones du "vagin modifié " de la chèvre no 4 . FIG. ro. Au faible grossissement montrant la réduction des lumières et des glandes de la paroi. FIG. II. Revêtement de type cervical de la lumière principale du "vagin modifié ".

FIG. I2. Structure de type vésicule séminale située sur la paroi intérieure de la lumière réduite.

FIG. I3. Coupe de la partie inférieure du "vagin modifié " montrant des structures de type vésicule séminale et cervical.

FIG. I4. Revêtement intérieur de la lumière réduite du côté opposé à la structure de type vésicule séminale. 

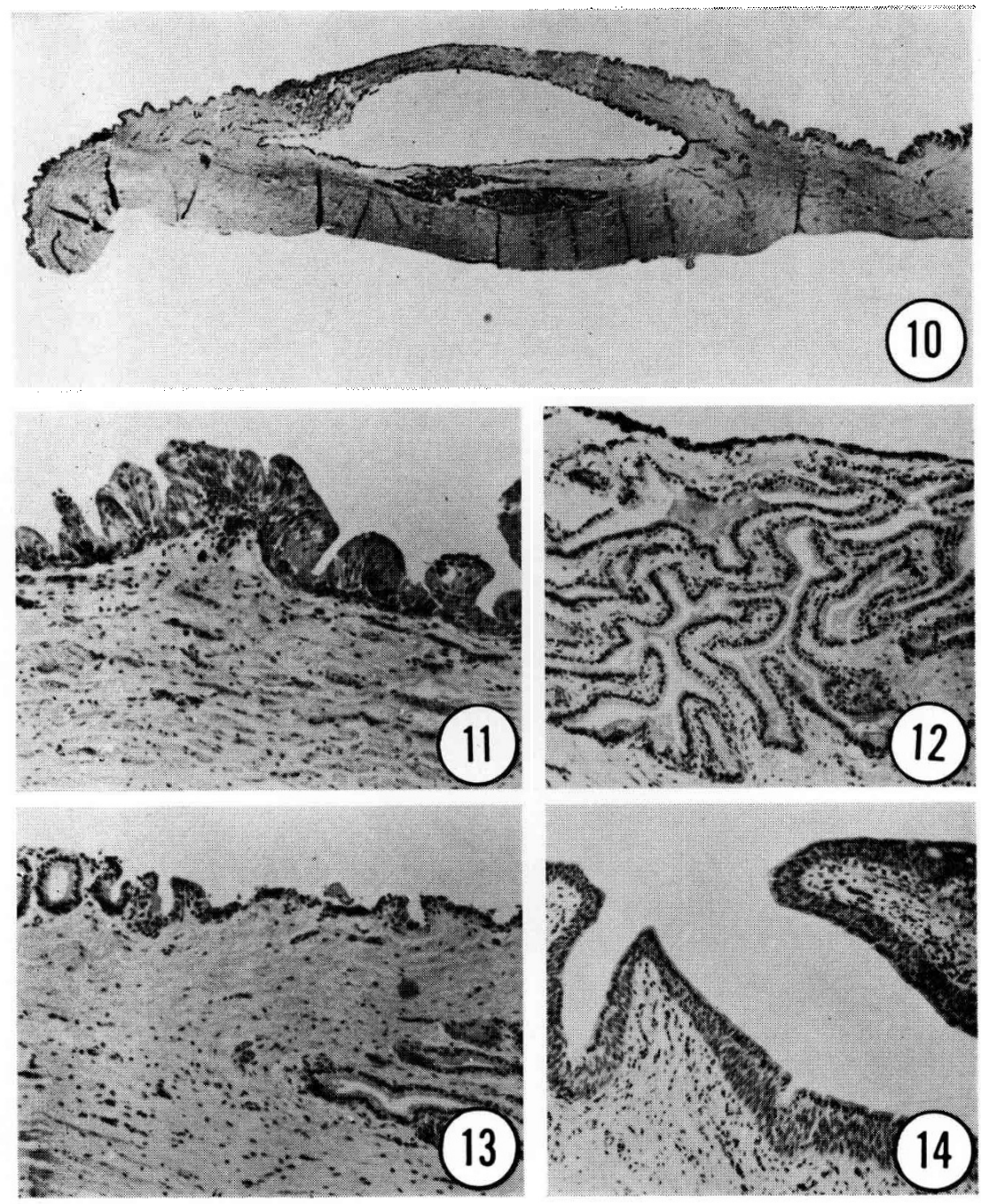

P.-K. BASRUR and H. KANAGAWA 


\section{PLATE V}

FIGS. 5 and 16. Sections of inactive abdominal testes.

FIG. I5. Goat No. I6 showing seminiferous tubules devoid of germ cells. Note that the tubules are regular and that the interstitial cells are sparse.

FIG. 16. Goat No. I7 showing distorted seminiferous tubules and extensive interstitial tissue.

\section{PLANCHE V}

Fig. 15 et 16 . Coupes de testicules abdominaux inactifs.

Fig. I 5. Chèvre $n^{0}$ I 6 présentant des tubes séminifères dépourvus de cellules germinales. Noter que les tubes sont réguliers et que les cellules interstitielles sont clairsemées.

FIG. 16. Chèvre $n^{\circ} 17$ présentant des tubes sćminifères déformés et un tissu interstitiel très développé. 


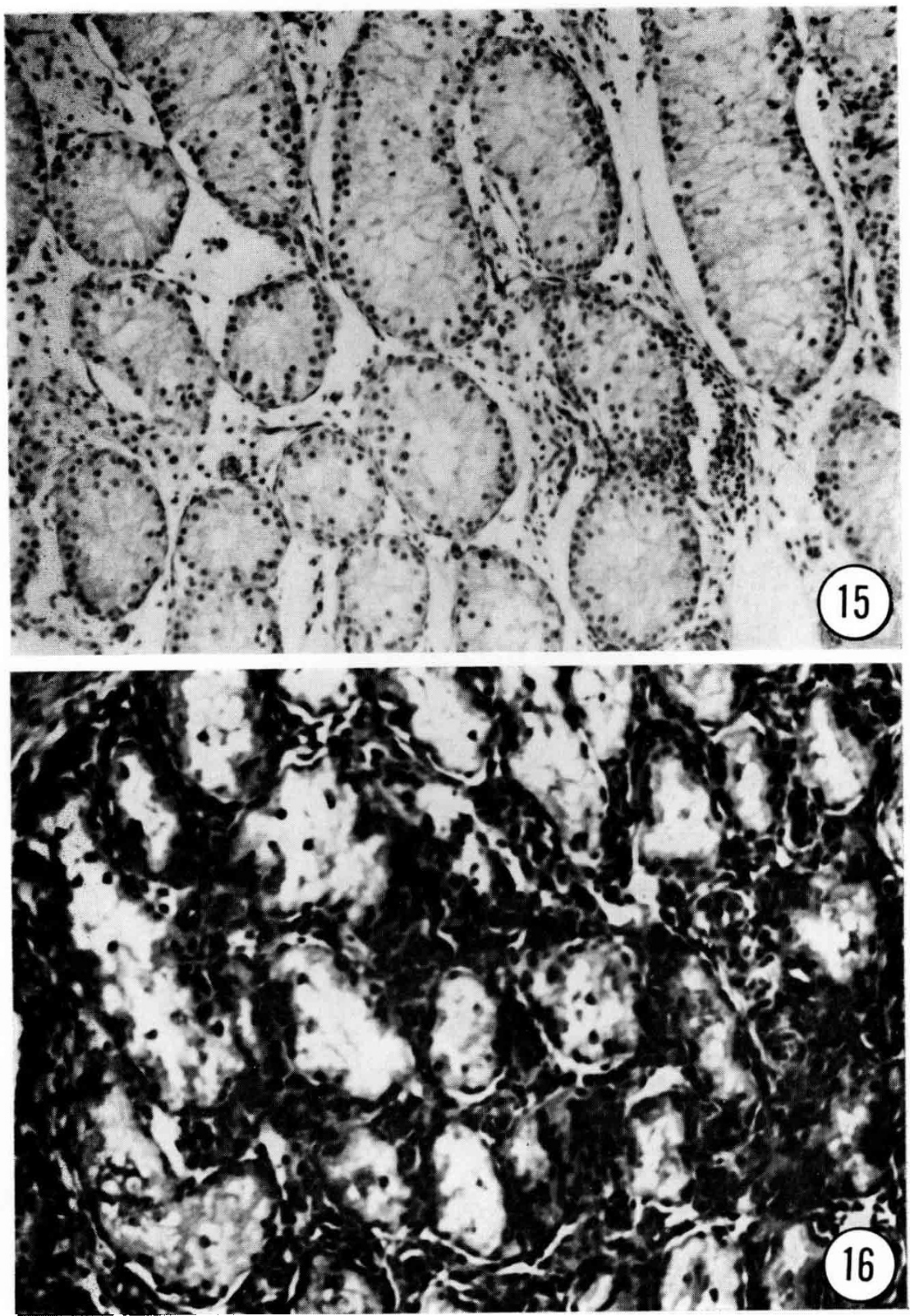




\section{PIATE VI}

FIGs. I7 and I8. Electron micrographs of the abdominal testes from Goat No. I3 and Goat No. I9 showing extreme distortion of the seminiferous tubules. Note the " patterned" basement membrane and collagen bundles (Fig. I7) and the thickened intercellular junction with fibre-like projections (Fig. I8).

\section{PLANCHE VI}

FIG. I7 et I8. Vues au microscope électronique de testicules abdominaux des chèvres no ${ }^{\circ} 3$ et I9 montrant l'extrême déformation des tubes séminifères. Noter le modelé de la membrane basale des faisceaux de collagène (fig. 17) ainsi que la jonction intercellulaire épaissie avec des projections de type fibreux (fig. I 8 ). 
Ann. Génét. Sél. anim., I969, 1 (4)

P1. VI
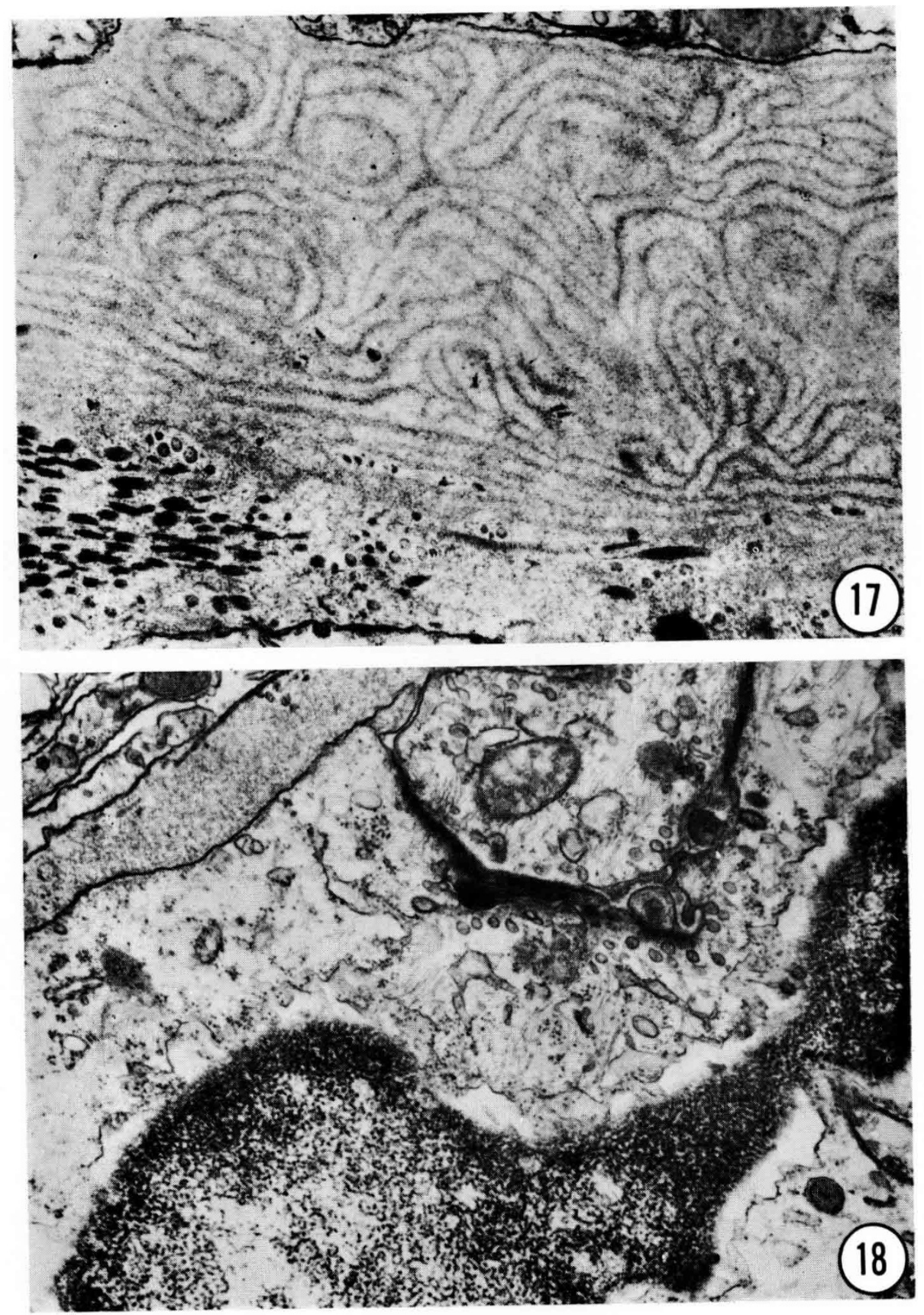

P.-K. BASRUR and H. KANAGAWA 


\section{PLATE VII}

FIGs. 19-22. Testicular sections of gcats showing meiotic activity in scme seminiferous tubules FIG. I9. Goat No. 2 showing a presumptive spermatocyte (arrow').

FIG. 20. Another area from the same testes (Goat No. 2) shoring extreme tubular degeneration.

FIG. 21. Section of the abdominal testes in (joat No. 5 shoneing some meiotically active seminiferous tubules and aggregations of germ cells and /or spermatozox between tubules.

FIG. 22. A section of the abdominal testis from Goat No. I+ showing some pachytene stages.

\section{PLANCHE VII}

Fıg. 19 à 22. Sections testiculaires de chèvres présentant une activité méiotique dans quelques tubes séminifères.

FIG. I9. Chèvre $n^{\circ} 2$ avec un présumé spermatocyte (flèche).

Fig. 2o. Une autre zone du même testicule (chèvre $n^{\circ} 2$ ) montrant une dégénération tubulaire très poussée.

Fig. 21. Section d'un testicule abdominal de la chèvre $n^{\circ} 5$ avec des tubes séminifères méiotiquement actifs et des agglomérations de cellules germinales et/ou des spermatozoïdes entre les tubes.

FiG. 22. Une section d'un testicule abdominal de la chèvre $n^{\circ}$ I 4 avec quelques stades pachytènes. 

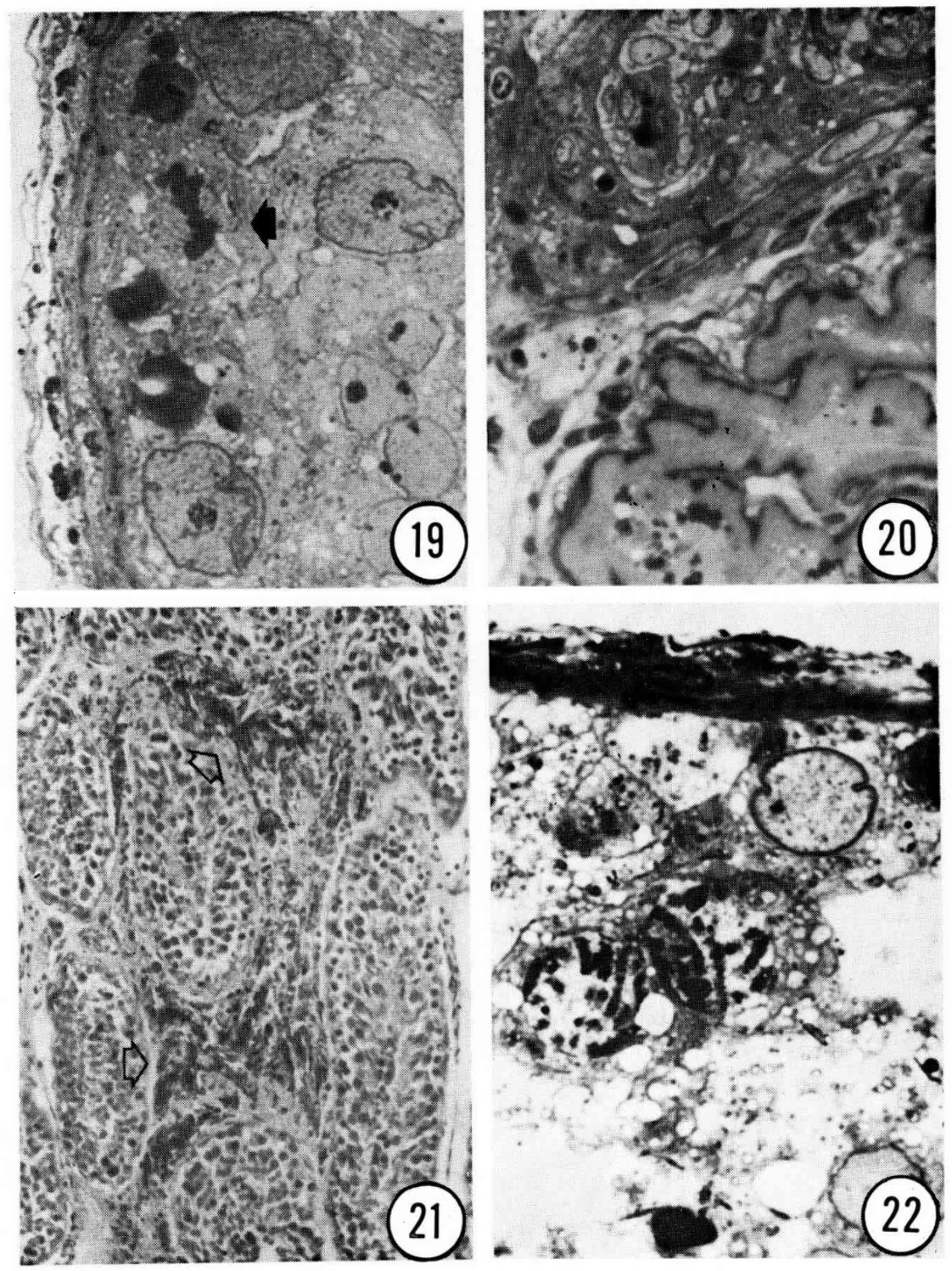


\section{PLATE VIII}

FIGS. 23-25. Electron micrographs of developing spermatozoa in Goat No. I4 showing distortions of the head.

\section{PLANCHE VIII}

Frg. 23 à 25 . Vue au microscope électronique de spermatozoïdes en développement chez la chèvre $n^{\circ}$ I 4 et montrant les distorsions de la tête. 
Ann. Génét. Sél. anim., 1969, 1 (4)

P1. VIII
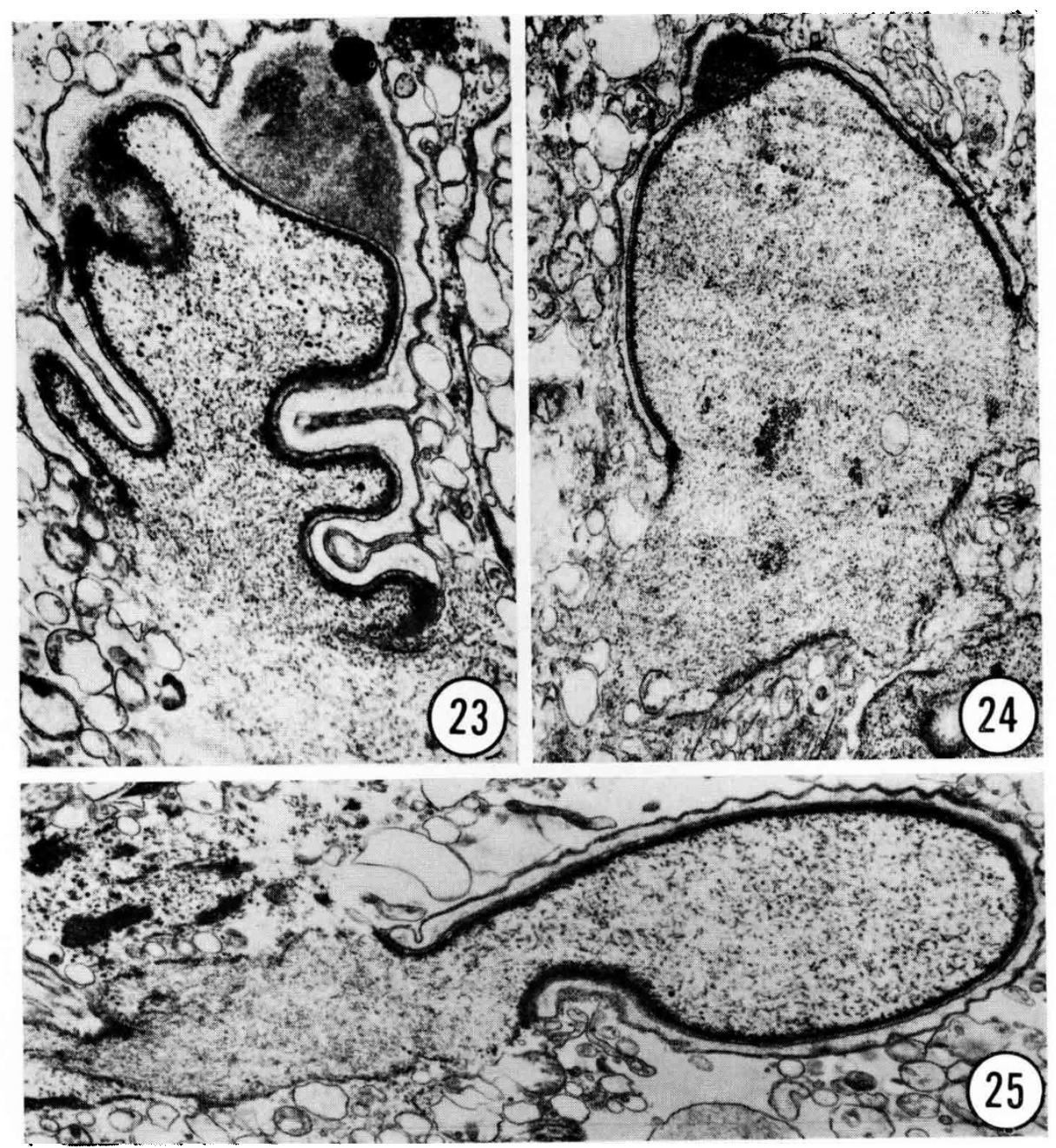

P.-K. BASRUR and H. KANAGAWA 


\section{PLATE, IX}

FIGS. 26-30. Sections of epididymis.

FIG. 26. Section from Goat No. 4 showing the typical epididymal ducts noted in a majority of intersex goats. FIG. 27. Low poner micrograph of the gonad shoning epididymis and testes in Goat No. 5. Note the ducts filled with dark substances.

FIG. 28. Epididymis (Goat No. 2) filled zeith dark pigments.

FIG. 29. Epididymis (Goat No. I) showing accumulation of spermatozoa in the lumen and infiltration of macrophages in the surrounding connective tissuc.

FIG. 30. The spermatocoel-like structure noted in Goat No. I 4 with masses of spermheads betreen and within the ducts.

\section{PLANCHE IX}

Fig. 26 à 30 . Coupes de l'épididyme.

Fig. 26. Sur la chèvre no $_{4}$ une section montrant les conduits épididymaires typiques de la majorité des chèvres intersexuées.

FIg. 27. Vue à petit grossissement de la gonade montrant l'épididyme et le testicule de la chèvre $\mathbf{n}^{\mathbf{0}} 5$. Noter les conduits emplis de substances noires.

FIG. 28. Épididyme (chèvre $\mathbf{n}^{\circ}$ 2) remplie de pigments noirs.

FIG. 29. Épididyme (chèvre $n^{\circ}$ r) montrant l'accumulation de spermatozoïdes danş la lumière et l'infiltration des macrophages dans le tissu conjonctif environnant.

Fig. 30. La structure de type spermatocèlien notée chez la chèvre $n^{0}$ I $_{4}$ avec des masses de têtes de spermatozoïdes entre et dans les conduits. 

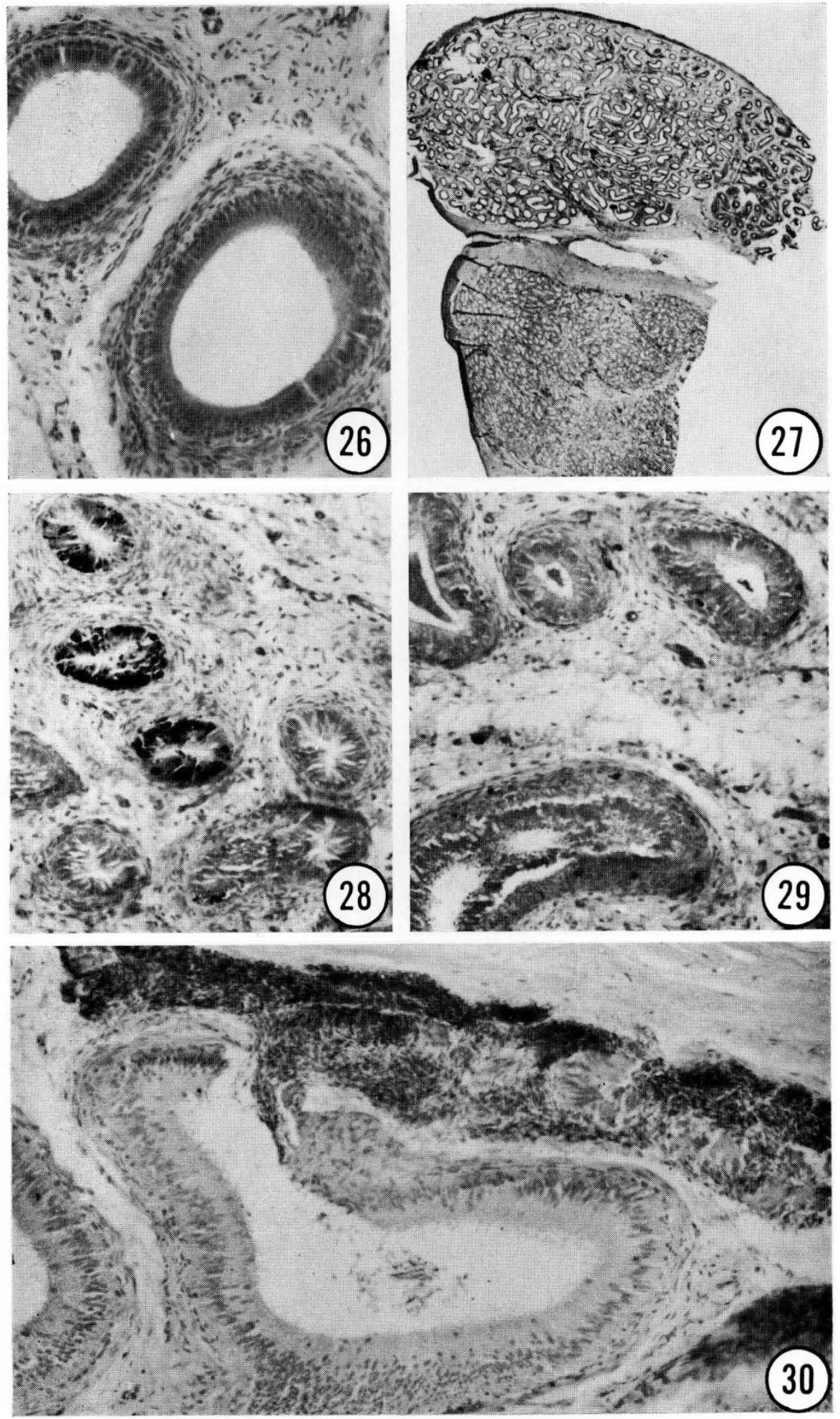

P.-K. BASRUR and H. KANAGAWA 


\section{PLATE $\mathrm{X}$}

FIG. 31. A female goat karyotype showing 60 acrocentric chromosomes including a pair of $\mathrm{X}$ chromosomes.

\section{PLANCHE $\mathrm{X}$}

Frg. 3r. Caryotype de chèvre femelle avec 60 chromosomes acrocentriques, dont une paire de chromosomes $\mathbf{X}$. 


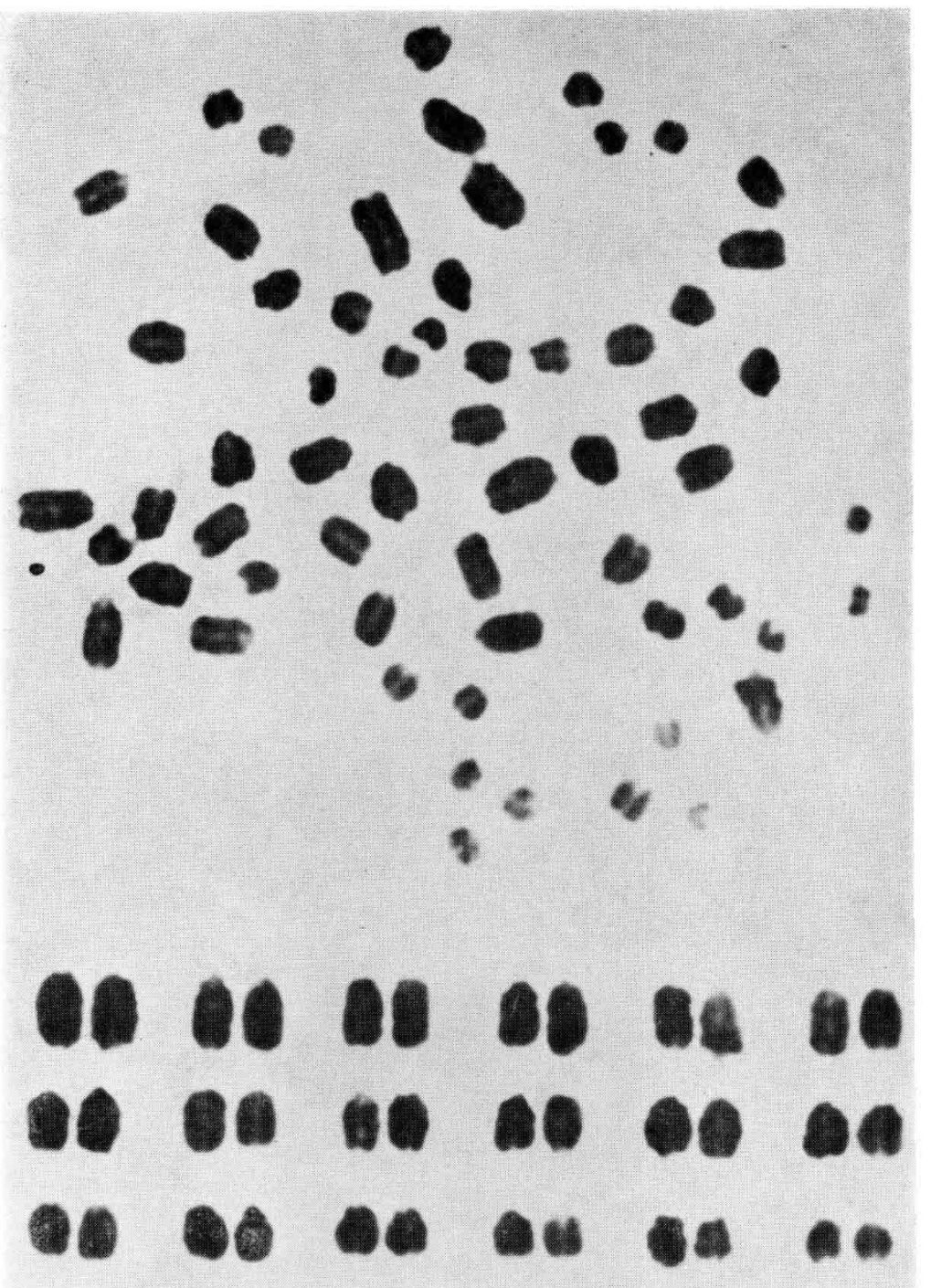

문

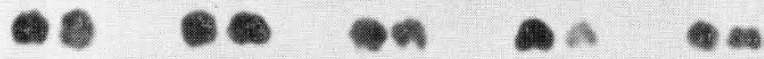

(31)

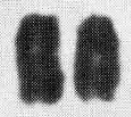




\section{PLATE XI}

FIG. 32. A male goat karyotype showing 60 chromosomes including the long acrocentric $X$ chromosome and the small metacentric $Y$ chromosome.

\section{PLANCHE XI}

FIG. 32. Caryotype de bouc avec 60 chromosomes dont un $\mathrm{X}$ long et acrocentrique et un petit $\mathrm{Y}$ métacentrique. 


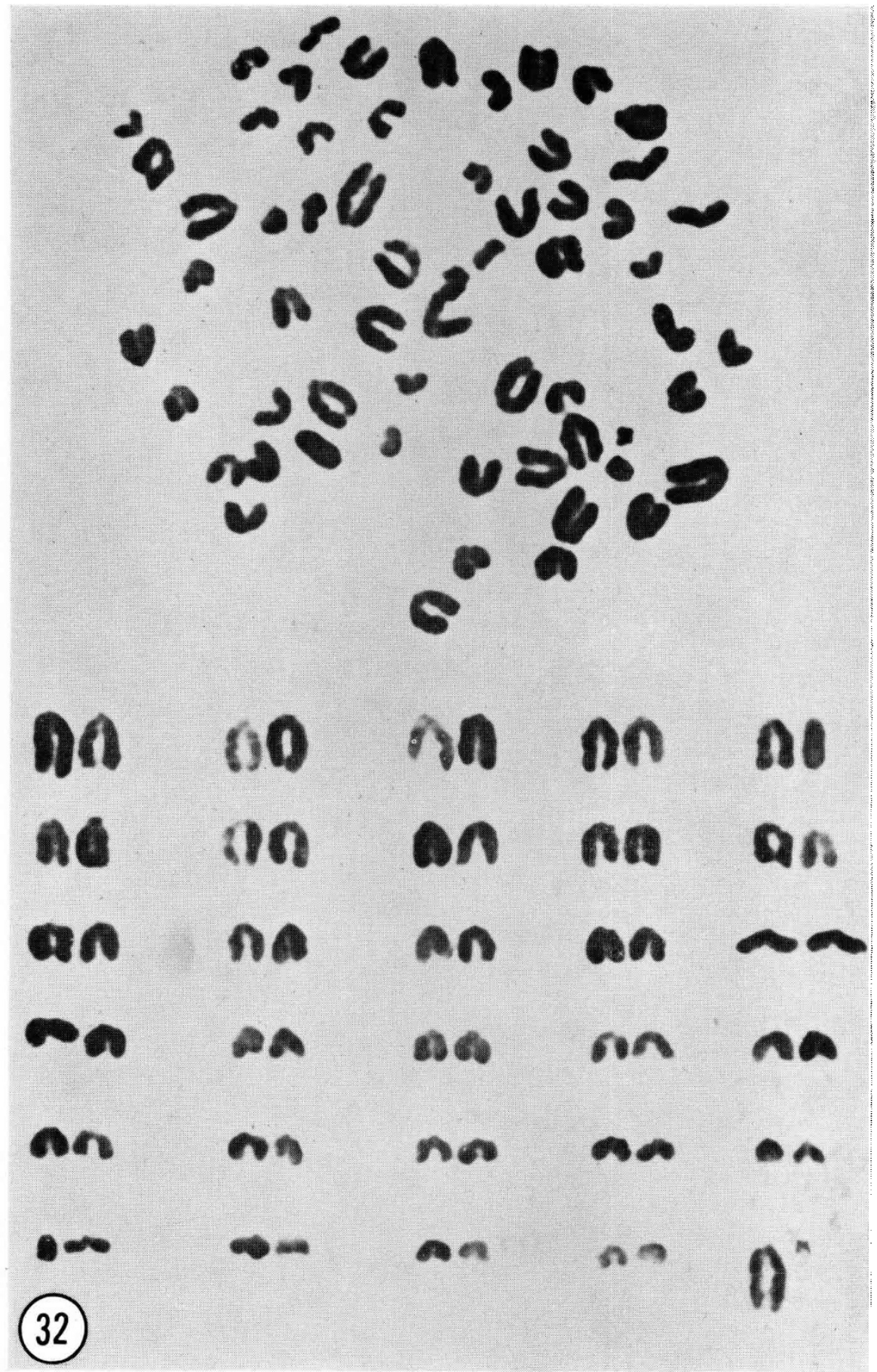

P.-K. BASRUR and H. KANAGAWA 
